\title{
The State's Obligation to Protect the Individuals Lives from the Consequences of Domestic Violence
}

\author{
Vilard Bytyqi \\ Faculty of Public Safety, Kosovo Academy for Public Safety \\ St. Gjergj Kastrioti Skënderbeu - 42000 Vushtrri, Kosova \\ Tel.Fax: +37-745-490017 E-mail: vilard.bytyqi@rks-gov.net
}

Submitted: Feb 15, 2017; Reviewed: Mar 17, 2017; Accepted: Mar 20, 2017

\begin{abstract}
The aim of this paper is to treat the important aspects, which deal with State's obligations to protect individuals lives from the consequences of the domestic violence. Thus, domestic violence is a concerning issue, which derives many consequences that sometimes are irreparable. In many cases, the State is obliged to save individuals lives from the effects of the domestic violence. The State will not be held responsible in all the cases for the consequences of the domestic violence. Due to the scarcity of the regulation of all the situations in the normative terms, the judicial practice that considers the cases of the right to live has evolved greatly, such that it has set many standards in case of increased institutional responsibility towards the consequences caused by the domestic violence. Due to a practical elaboration, the paper as a such will focus in the treatment of cases from the judicial practice in the context of the State's obligation to save individual's life, whose life is endangered. Furthermore, there will also be an emphasis in the protection of the right to life and the State's responsibility in relation to the consequences caused by the actions of the third parties.
\end{abstract}

Keywords: Domestic Violence; Human Rights; State's Responsibility; The Right to Life

DOI: 10.20956/halrev.v3i1.897

\section{INTRODUCTION}

The right to life is a right that is guaranteed by the Constitution of Kosovo. Under the provision of Article 25, par. 1 it is specified that "Every individual has the right to life". The right to life is known as the most basic individual right, as a precondition to enjoy other rights. Considering that our justice system has banned the death penalty, the right to life still remains an absolute right, since it cannot be limited under any circumstances.

The right to life within the legal system in Kosovo, is also guaranteed by interna- tional acts which are directly applicable in Kosovo. ${ }^{1}$ Some of these international documents provide this right directly, while others indirectly. ${ }^{2}$

\footnotetext{
Article 22, Constitution of Kosovo

International acts that are directly applicable in Kosovo under Article 22 of Constitution of Kosovo, are: (1) Universal Declaration of Human Rights; (2) European Convention for the Protection of Human Rights and Fundamental Freedoms and its Protocols; (3) International Covenant on Civil and Political Rights and its Protocol; (4) Framework Convention for the Protection of National Minorities; (5) Convention on Elimination of all forms of Racial Discrimination; (6) Convention on Elimination of all forms of Discrimination against Women; (7) Convention on the Rights of the Child and (8) Convention against Torture and Other Cruel, Inhuman or Degrading Treatment or Punishment.
} 
Primarily, the State is obliged to protect individual's life. "By recognizing such a right, this obligation for protection is undertaken by the State in some cases: when death is caused by the State police forces, when it derives due to the risks arising from the operations of local authorities, when it is caused by the third parties or by the person itself." 3 Therefore, the State will be held responsible even in cases when it is obliged to act and it will not act. Thus, this issue has to do with the responsibility as an objective circumstance.

The State's obligation to protect the individuals lives by its actions and inactions is an unchangeable obligation within its obligations to protect the life, the physical integrity and other citizen's moral and material values within the state's legal order. Such obligations derive from the legal norms ius cogens, which are part of the legal order as original State norms that are issued by the internal legislative procedures, or as legal norms of international law, which through the ratification procedure, or direct application by the Constitution, have become part of the internal legal order and as such, they produce binding legal consequences for the state bodies. As a result, in some circumstances they are responsible to act or refrain from acting.

Moreover, the State's primary obligation is to create an adequate and necessary legal framework in order to protect and guarantee the right to life, as a primary obligation in relation to the obligations that arise from the effective protection and guarantee of individuals lives. While drafting the supporting legal framework, the obligations of state officials in terms to act within the framework of the judicial institutions, or in other cases, we need to carefully insist that in any circumstances the regulations should be more detailed, by regulating all the possible actions that can or must be taken by the State forces and officials, and also making clear all the authorizations and obligations, which they must have in concrete cases.

According to the internal legal order in Kosovo, the protection of individual's right to life has a comprehensive character. There is no limit to protect individuals lives regardless any circumstances. The importance of protecting the right to life is the same, without any distinction. Thus, this right is seen under the right to equality, which excludes any discriminatory or preferential treatment.

The biggest problems as per the guarantee of this right are the practical problems of implementation. In some limited cases it might happen that the state officials have not considered the consequences of taking their actions, or even the consequences of their inactions, which might lead to wrong, disproportionate, hasty and deficient concrete actions. As a result, this might lead to negative effects for life and individual's integrity, by allowing directly to have violation of right to life, a right that is guaranteed by an absolute character.

\footnotetext{
Positive obligations under the European Convention of Human Rights - Guidelines for use of the European Convention of Human Rights (Council of Europe, 2002), p. 72
} 


\section{ANALYSIS AND DISCUSSION}

\section{The Protection of Right to Life through the Provisions of Law on Protection against Domestic Violence}

The Law on protection against domestic violence " "aims to prevent domestic violence by all means, taking appropriate legal measures for family members who are victims of domestic violence, paying special attention to children, to elderly people and those with disabilities." "Security measures are imposed in order to prevent domestic violence, to protect people who are exposed to violence, by avoiding the circumstances that impact or might impact on doing further actions."

Not infrequently, the consequences of domestic violence committed against its members may be unrecoverable for individual's life. The poor relationships between the subjects that are defined by the law on protection against domestic violence ${ }^{7}$ by using violence may even lead to the loss of individual's life.

Domestic violence is still one of the most prevalent forms of violence that is affecting mostly women and children in Kosovo. The Kosovo Police data report violence cases with approximately 1000 victims per

\footnotetext{
This Law was approved by Constitution of Kosovo, on July 1, 2010, while it was decreed by the President of Kosovo on 15.07.2010

5 Article 1, Law nr. 03/L-182 on domestic violence protection

Ibid, Article 3, par.4

Family relationships are considered people that: are engaged or were engaged; are married or were married; have extramarital union or had extramarital unions live in a common economy or have lived in the same economy; use the same house and have blood relations, marriage, adoptation, or a custodial relationship including parents, grandparents, children, nephews, nieces, brothers and sisters, aunts and cousins; parents of a common child; or procedural parties in a family relations context;
}

year that are assisted by Kosovo institutions. In more than $80 \%$ of the cases the victims are women, followed by children and elderly men. ${ }^{8}$ During 2010, the Kosovo Police reported a total of 944 incidents of domestic violence. In six of those incidents, the victims were killed by the perpetrator. While, four other incidents where severe enough to be classified as attempted murder. The majority of the $81 \%$ of victims during this period were women or girls. ${ }^{9}$ The above-mentioned data reveal that the results of the violence in family have had the consequences of loosing individual's life.

It is not uncommon, yet not a normal situation, the fact that the use of violence in family leads to losing a life. Therefore, in this case the trial would include the State's responsibility or obligation to protect the individual's life from the effects of domestic violence. In other words, when does the State begin to protect people's lives from domestic violence?

If we analyze the flow and the circumstances of the incidents, we could ascertain that in many cases it is impossible to protect individual's life. However, the State's responsibility to protect people's lives is inevitable when individual's life is in danger or it may potentially be exposed to violation of physical integrity.

In many cases, the State is obliged to protect individuals, whose lives are at risk as a result of actions made by the third parties that may arise from the use of domestic

\footnotetext{
The evaluation report of the Kosovo program against domestic violence and the action plan 2011 - 2014 (Prishtina, 2015), p. 10

9 The evaluation report of the Kosovo program against domestic violence and the action plan 2011 - 2014 (OSCE, Prishtina, 2012), p. 10
} 
violence. If protecting the right to life is not effective, even the state will be held responsible for the irreparable consequences.

Under the provisions of Law on protection against domestic violence, domestic violence can be reported by the police, or by petitions for protection and emergency protection orders within the court jurisdiction specified by law. Regarding the request for emergency protection, the court decides within twenty four (24) hours, while for protection order, the decision is taken in fifteen (15) days after the request. ${ }^{10}$ "The competent court shall issue a protection order or emergent protection order in cases when the perpetrator may put at risk the safety, health and welfare of the protected party and the person with whom the protected party has a familiar relationship, which should be also protected by the protection order or the emergency protection order."

Therefore, from the moment that the public institutions understand the threat and they fail to do their job in accordance with the obligations that they have to take within the limited deadline, they will be directly responsible for the failure to protect individual's life. Not infrequently, the situations in practice are easy, they usually appear to be very complicated due to the fact that the objective circumstances have an impact in the 10 Under the interpretation of the provisions of Article 16.1 of Law on Protection Against Domestic Violence, in the Commentary Law nr.03/1-182 on domestic violence protection, by authors: Haxhi Gashi and Ruzhdi Berisha, published in Prishtina in 2014, in relation to the deadline for the request, they specify that "the deadline is counted from the next day after the request is submitted. Thus, the day when the request is submitted is not counted. From the next day, the court may start the procedure to decide and it has to end it within 24 hours. The deadline in 24 hours is the maximum time that the court should bring a decision."

11 Article 17, paragraph 1, Law on Protection Against Domestic Violence concrete cases.

The efficiency of the norms of Law on Protection Against Domestic Violence is directly related to their practical application in concrete cases. By law, the authorities that are obliged to implement these provisions are the Police and Courts.

Moreover, if we analyze the provisions of Law on Protection Against Domestic Violence, we could say that the State may fail to protect individuals whose life is endangered in cases when within the due date the legal authorities would not react to take any legal actions which contribute to the individuals integrity and life saving, or in cases when it should be decided to take actions that are provided by law but in practice do not show effectiveness, or even in cases when the official states are responsible for implementing the measures but they ignore the effective implementation of the measures, by creating in this way the chance to put in danger the individual's life and integrity.

\section{The Protection of Individuals against Lethal Violence Caused by Others, with a Special Emphasis on Family Relationships} In many circumstances, the State would be held responsible in case of violation of the right to life which is guaranteed under the Article 25 of the Constitution of Kosovo, even if the death is caused by the third parties. However, the circumstances and the development of such situations requires a very careful treatment, still the responsibility relies on the State due to the failure to fulfil the obligations by its organs.

The State is responsible for the cases that are reported in its bodies, while un- 
avoidable responsibilities are held especially in cases when the legislation implies to take measures for individual's safety and physical integrity, which is directly related to overcoming legal deadlines where the State bodies are obliged to act but they do not act or they fail to act.

According to the practice of the European Court of Human Rights, "the main obligation of the national authorities "is to guarantee the right to life by creating a concrete penal legislation in order to prevent the infringement" but also to "take practical measures to protect the person whose life is at risk from criminal acts of other individuals". ${ }^{12}$ In any case, the State has no amnesty even in domestic violence, in regards to the attacked parties, it is obliged to protect the person whose life is at risk from other people.

Regarding the State's responsibility to protect individuals whose life is at risk from the third parties, directly related to the implementation of the provisions that derive from the legislation for domestic violence protection, the Kosovo Constitutional Court in the case KI 41/12 claimed by "Gëzim and Makfire Kastrati against Municipal Court in Prishtina and Kosovo Judicial Council"13 has concluded that there was a violation of right to life, provided in the Article 25 of the Constitution and the Article 2 of European Convention on Human Rights, and the responsibility relied on the law enforcement institutions which were obliged to react on

12 Paragraph 115, Osman v. United Kingdom of 28th October 1998

13 The case was filed on 17th of April 2012 in the Constitutional Court, from the claimants Mr. Gëzim and Mrs. Makfire Kastrati, parents of the deceased D. K. The Court has decided for the case on 26th of February 2013 the case.

If we analyze the case further, we could see that the submitters are claiming, that the Municipal Court in Prishtina, did not act in accordance to the Law on Protection Against Domestic Violence, nr. 03/L-182 and the failure is not a result of a judicial decision, but it is a result of the inaction of Municipal Court in Prishtina. ${ }^{14}$

Based on the facts, it could be seen that D. $\mathrm{K}^{15}$ was in an extramarital union with $\mathrm{A}$. $\mathrm{J}$ and they have got a child, namely daughter. Due to their bad relationship, on 17th of January 2011, D. K filed a lawsuit to end the extramarital union with A. J. After filing the lawsuit, D. K took her daughter and they both went to her parents to live. Furthermore, on 26th of April 2011, as a result of continuity threats by A. J towards D.K and their daughter, D. K filed a request in Municipal Court in Prishtina to issue an emergency protection order, based on the Article 15 of the Law on Protection Against Domestic Violence, Nr. 03/L-182. On 18th of May 2011, D. K died after receiving wounds to the neck with a gun that was fired by A. J. ${ }^{16}$

The submitters pretend that the $\mathrm{Mu}-$ nicipal Court of Prishtina, with its inaction in accordance to its constitutional and legal obligations to handle the request for an emergency protection order, has violated the individuals rights of $\mathrm{D}$. $\mathrm{K}$ and indirectly also the claimants rights, which are guaranteed by Article 25, Article 31, Article 32 and Article 54 of the Constitution of the Republic of Kosovo, and also with the Article 2, Article

$14 \quad$ Ibid, paragraph 4

15 The names of the victim and the doer will be written only by initials as the Constitutional Court has mentioned in it's decision.

16 Ibid, paragraphs 16, 17, 18, 19, 20 and 21 
6 and Article 13 of the European Convention for the protection of Human Rights and Fundamental Freedoms. ${ }^{17}$ (17. Paragraph 27).

Moreover, the claimants point out that "the Municipal Court of Prishtina had an obligation to react within twenty four (24) hours from the moment D. K filed the request for an emergency protection order. This court did not act at all in this case. The review of the relevant legislation shows that in terms of remedies in cases of action by the Municipal Court of Prishtina, when it should act as obliged by Article 19 of the Law on Protection Against Domestic Violence, Nr. 03/L-182, it can be concluded that there are no legal remedies which could be used by the victim in cases of failure of the Municipal Court. ${ }^{18}$ Claimants also point out that "Article 19 of the Law on Protection Against Domestic Violence provides only appeal proceedings against judicial decisions for protection orders, but it does not provide remedies for the claimants in cases when the court does not act at all. ${ }^{19}$ Claimants also insist that, "in this case, not only the use of remedies is not effective, but it is impossible to use them, because, in fact, remedies do not exist at all." 20

Furthermore, the claimants also claim that "the lack of legal, theoretical and practical remedies, in this case, can be considered as a violation of individual rights. Article 13 of the European Convention for the Protection of Human Rights and Fundamental Freedoms and Article 32 of the Constitution guarantee the right for legal remedies. Law on Protection Against Domestic Vio-

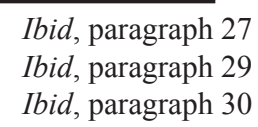

Ibid, paragraph 32 lence provides no remedies for claimants for violence protection order in cases where the court does not act at all. Thus, the inability to access the remedies in the below-mentioned case, implies that there is a violation of the rights which are guaranteed by the Constitution and conventions". ${ }^{21}$

In reviewing their claim for violation of Article 25 of the Constitution and Article 2 of the European Convention for the Protection of Human Rights and Fundamental Freedoms, the claimants refer to the case law of the European Court of Human Rights, stating that "this court, in the case Osman v. United Kingdom, has indicated that the person who claims that his right to life has been violated, must prove that (1) the authority knew or should have known at the time that there is a real risk for a person due to the criminal acts of a third party, and (2) failed to take measures within the scope, which might have prevented the risk, if judged reasonably. As a result, this indicates that the State is obliged to act when the preconditions are proved by the person, on the contrary it indicates that it has violated the person's right to life. ${ }^{22}$

The Court that is handling the case is pointing out three issues raised. The first two issues are related to the failure of State institutions to protect individual's life and the Law on Protection Against Domestic Violence and the issue of whether or not the Law on the Kosovo Judicial Council provides an effective remedy for the protection of claimants rights. The Court has handled the claim for violation of the right to a fair and impartial trial, provided in Article 31 of the Con${ }_{21} \quad$ Ibid, paragraph 35

22 Ibid, paragraph 26 
stitution and Article 6 of the European Convention for the Protection of Human Rights and Fundamental Freedoms, and as a result it was considered unnecessary.

In regards to the violation of the right to life, the court with its decision "...notes that from the documents filed in the Court, it can be concluded that the relevant authority which in this case is the Municipal Court in Prishtina, should have known about the risk when the request for emergency protection order was submitted. They should have known the risk due to the fact that $\mathrm{D}$. $\mathrm{K}$ has explained in a chronological order the flow of the relationship as it kept going worse and worse, and even specifying the death threats from her ex-husband and providing evidence for the preliminary report about the threats at the police." ${ }^{23}$ The decision specifies that "The Municipal Court in Prishtina has previously handled a case that was initiated by D. $\mathrm{K}$ for termination of her extramarital union and for assigning child custody of the deceased and her ex-partner, when serious problems started to happen between them, which later resulted in various threats." ${ }^{24}$ Based on the decision, "the Municipal Court in Prishtina was responsible for taking measures stipulated by the Law on Protection against Domestic Violence, and its inaction in violation of constitutional obligations that derive from Article 25 of the Constitution and Article 2 of the European Convention for Protection of Human Rights and Fundamental Freedoms." ${ }^{25}$ Moreover, the Court found violations of the right to effective legal remedy which resulted in violations of the right

Ibid, paragraph 61

24 Ibid, paragraph 62

25 Ibid, paragraph 62 to life due to the negligence of courts and other state bodies to protect effectively the victim which was a divorced woman killed by her ex-husband. ${ }^{26}$

\section{Does the Failure of Court to Act by the Deadline Impinge or Not the Right to Life in the Cases of Domestic Violence?}

Based on the above-mentioned case, we saw that if the court filed an order for protection with the aim of not endangering and protecting the life and physical integrity of the individual but the court did not act within the timeframe that was obliged by the legal norms in force, then the state body for law enforcement will be responsible, because it has failed to implement the legal norms.

There are numerous dissenting opinions regarding the fact that the State is responsible if it has not reacted within the legal limits, even though it was obliged to act. However, in this paper we will raise the findings of competitive and dissenting thoughts of Robert Carolan, judge in the Constitutional Court of Kosovo, in the decision of KI 41/12. He states that:

"In this case, the claimants admit that any officer has not done anything to cause the death of $D$. K. The claimants imply that if the municipal judge had acted upon the D. K's request for a protection order, she would not be killed, and this inaction by the Municipal Court has caused her death. "27

26 Hasani, I. \& Cukalovic, I. (2013). Commentary - Constitution of the Republic of Kosovo. Prishtina: GIZ, p. 107

27 Dissentient and concurring opinion from the judge Robert Carolan in the decision of the Constitutional Court of the date 26.02.2016, in the case nr. KI 41/12, the claimants Gëzim dhe Makfire Kastrati against the Municipal Court of Prishtina and the Kosovo Judicial Council, p. 4 
According to the judge, "this is a wrong conclusion. Protection order would have provided Police with an additional remedy to keep the killer of the D. K away from her. But, it could have not guaranteed that he would not comity a crime, which tragically he did. For as much as the opportunity of the severe penalty based on the law can or should be established in terms if the killer of D. $K$ is arrested and convicted for murder has not stopped him in the act of killing the D. K, it is speculative to suppose that the court order for protection in this case would have been sufficient to stop him from committing a murder or that Police would have been capable to catch him in the restricted contact with $D$. K before he committed a murder. "28

\section{CONCLUSION}

The right to life is a right guaranteed by the Constitution and by international acts. The State has the obligation to protect individual's life if it is threatened by the consequences of the actions of third parties that may derive as a result of the domestic violence. The state will not be held responsible for all cases of domestic violence that have resulted in a loss of individuals life, but it will never be exempt from the responsibility in cases when it was obliged to act but it did not react to save the individual, whose life was endangered.

The State's obligation to protect individuals, whose life is endangered by domestic violence, starts from the moment of receiving the information about the real risk and the possible consequences that may arise

28 Ibidem. and the sufficient time to organize for protection the right to life and preventing the irreparable consequences.

In normative terms, especially through legislation for protecting individuals from domestic violence, the judicial protection has determined the legal limits within which the law enforcement officials are obliged to act. In these cases, if there is no action to protect the individual's life and integrity within the legal deadline, it is for sure that the irreparable consequences will be charged to the State, as being responsible for not taking actions in order to protect individual's life.

\section{BIBLIOGRAPHY}

Constitutional Court. (2013). Dissentient and concurring opinion in the case KI 41/12. Gëzim and Makfire Kastrati against the Municipal Court in Prishtina and the Kosovo Judical Council.

Constitutional Court. (2013). The judgment in the case KI 41/12. Gëzim and Makfire Kastrati against the Municipal Court in Prishtina and the Kosovo Judical Council.

European Court of Human Rights. (1998). Case: Osman v. United Kingdom, viewed 15 April 2016.

Gashi, H \& Berisha, R., (2014). Commentary Law nr.03/l-182 on domestic violence protection. Prishtina: GIZ.

Hasani, I. \& Cukalovic, I. (2013). Commentary - Constitution of the Republic of Kosovo. Prishtina: GIZ

Kombe, JFA. (2002). Positive obligations under the European Convention of Human Rights - Guidelines for use of 
the European Convention of Human Rights, Council of Europe.

Ministry of Justice. (2015). The evaluation report of the Kosovo program against domestic violence and the action plan $2011-2014$.

The Law nr. 03/L-182 on domestic violence protection 2010.
The trial for the requests for protection orders in cases of domestic violence in Kosovo, 2012.

United States Department of State, Bureau of Democracy, Human Rights and Labor. (2014). Country Reports on Human Rights Practices for Kosovo, viewed 10 April 2016. 